\title{
Profil Hematologi Sapi Bali pada Perioda Kebuntingan di Sentra Pembibitan Sobangan Badung, Bali
}

\section{(HEMATOLOGY PROFILE OF BALI CATTLE IN PREGNANCY PERIODS IN SOBANGAN BADUNG BREEDING CENTERS)}

\author{
Anak Agung Sagung Kendran ${ }^{1 *}$, Tjok Gde Oka Pemayun² \\ ${ }^{1}$ Laboratorium Patologi Klinik Veteriner, Fakultas Kedokteran Hewan, Universitas Udayana, \\ Jln. PB. Sudirman Denpasar Bali; \\ ${ }^{2}$ Laboratorium Reproduksi Veteriner, Fakultas Kedokteran Hewan, Universitas Udayana Jln. \\ PB. Sudirman Denpasar Bali. \\ *Email: gungkendran@unud.ac.id
}

\begin{abstract}
Abstrak
Sapi bali merupakan plasma nuftah yang harus dipertahankan keberadaannya. Berbagai usaha telah dilakukan seperti pembibitan agar populasi dapat ditingkatkan. Dalam pembibitan, manajemen kebuntingan akan mendapat perhatian yang utama. Periode kebuntingan pada sapi merupakan situasi penting dalam managemen kesehatan. Pada periode ini, status fisiologi harus dalam kondisi yang baik untuk menjamin kelahiran dan mendapatkan pedet atau anakan sapi yang cukup kuat dan mampu bertahan hidup. Sapi yang sedang bunting biasanya tubuhnya cenderung lemah dan rentan penyakit. Penelitian ini dilakukan untuk mengetahui gangguan fungsi organ atau tubuh lebih awal sebelum menampakkan tanda-tanda sakit. Parameter darah yang diamati dari 28 ekor sapi adalah: total eritrosit, total leukosit, Paced Cel Volume (PCV), Hemoglobin (Hb),differensial leukosit (limfosit, neutrofil, basofil, eosinofil dan monosit), Mean Corpuscular Haemoglobine (MCH), Mean Corpuscular Haemoglobine Concentration (MCHC), Mean Corpuscular Volume (MCV). Darah dengan EDTA diambil dari Vena jugularis. Data yang diperoleh dianalis dengan analisis ragam dengan prosedur analisis menggunakan program SPSS. Hasil penelitian ini menyatakan bahwa profil hematologi sapi bali pada tiap-tiap fase kebuntingan di Sentra Pembibitan Sobangan Badung tidak berbeda dengan sapi yang tidak bunting.
\end{abstract}

Kata kunci: Sapi bali; fase kebuntingan; Hb; eritrosit; leukosit; PCV; MCV; MCHC; $\mathrm{MCH}$.

\begin{abstract}
Bali cattle is germplasm that must be maintained. Various efforts have been made, such as breeding, so that the population can be improved. In the breeding, management of pregnancy will be the main thing to get attention. The gestation period in cattle is an important situation in health management. In this period, physiological status must be in good condition to ensure birth and get calf or calf, which is strong enough and able to survive. Cattle who are pregnant usually tend to weak and vulnerable diseases. This study was conducted to determine the disruption of organs or body functions earlier before showing signs of pain. Blood parameters observed from 28 cows were: The total erythrocytes, the total leukocytes, Packed Cell Volume (PCV), Hb, differential leucocytes (lymphocytes, neutrophils, basophils, eosinophils, and monocytes), Mean Corpuscular Haemoglobine (MCH), Mean Corpuscular Haemoglobine Concentration (MCHC), Mean Corpuscular Volume (MCV). Blood was taken from the jugular vein. The data obtained were analyzed by analysis of variance, with an analytical procedure using the SPSS program. The study results that the hematology of Balinese cattle at each pregnancy phase in Sobangan Badung Breeding Center is not different from non-pregnant cows.
\end{abstract}

Keywords: Bali cattle; pregnancy phase; Hb; erythrocyte; leukocytes; Hb; PCV; MCV; MCHC; MCH. 


\section{PENDAHULUAN}

Sapi bali merupakan sapi asli Bali, hasil domestikasi banteng yang memiliki kekhasan tertentu bila dibandingkan dengan sapi lainnya (Hardjosubroto dan Astuti, 1993). Daya adaptasinya yang tinggi, baik pada dataran tinggi, rendah, maupun berbukit (Kadarsih, 2004; Besung et al., 2019). Sapi bali adalah salah satu ternak yang tidak dapat dipisahkan dari kehidupan masyarakat petani di Bali (Laksmi et al., 2018). Sapi bali mempunyai empat fungsi penting yaitu: tenaga kerja pertanian, fungsi finansial, sarana keagamaan dan sarana hiburan (Masudana, 1990). Sapi bali betina memiliki performan reproduksi yang tinggi sekitar $80 \%$ dan selang beranak yang pendek (Ngadiyono, 1997; Martojo, 1990). Upaya pelestarian ini pada akhirnya akan dapat memenuhi kebutuhan daging konsumsi masyarakat. Diperkuat dengan dikeluarkan peraturan pemerintah nomor 48/Permentan/PK.210/10/2016 untuk memenuhi swasembada daging tahun 2026 dinyatakan bahwa sapi induk wajib bunting.

Hal paling utama dan penting untuk diperhatikan pada sapi bunting adalah ransum makanan dan perawatan kesehatannya. Sapi yang bunting harus mendapatkan ransum makanan yang baik, dalam arti kuantitas dan kualitasnya harus tepat. Sapi yang bunting memang memerlukan makanan yang lebih banyak dibanding sapi tidak bunting untuk memenuhi kecukupan energi. Jika tidak demikian maka sapi akan mengalami kesulitan saat melahirkan atau disebut Distokia dan akan mengalami banyak permasalahan juga saat persalinan. Perhatian terhadap ransum makanan bisa dilakukan setelah usia kehamilan sapi sudah lebih dari 2 bulan atau sedang dalam hamil muda. Sebab sapi harus mempersiapkan diri untuk pembentukkan jaringan-jaringan baru, seperti: janin, membran janin, pembesaran uterus atau rahim dan perkembangan kelenjar susu.
Harus tersedia protein yang cukup pada ransum makanan yang akan diberikan.

Karena kekurangan protein dapat menyebabkan turunnya ketahanan tubuh terhadap penyakit dan kematian pada pedet yang akan dilahirkan. Dibutuhkan 7-10\% protein, kalsium sekitar $0,5 \%$ dan phosphor $0,2 \%$. Saat memasuki usia 7 bulan atau 2 bulan sebelum melahirkan, sapi biasanya butuh asupan makanan yang lebih besar lagi guna meningkatkan bobot lahir pedet. Nutrisi yang dibutuhkan pun sudah berbeda dan lebih banyak lagi, seperti: protein yang dibutuhkan sekitar 12-12,5\%, kalsium sekitar $0,7 \%$ dan phosphor sekitar 0,3\%. Jadi perlu ada perbaikan pakan, yaitu dengan memberikan hijauan berupa rumput, jerami dan sejenisnya secara tak terbatas. Serta ditambah pakan penguat dengan kandungan protein $12 \%$ atau kirakira sekitar 1,5-2\% dari bobot sang induk. Dengan demikian maka sapi bunting akan memiliki daya tahan terhadap penyakit (Boer et al., 2002, Arthur and Noakes, 1996)

Ada berbagai jenis penyakit yang dapat mengganggu kesehatan sapi bunting dan janin yang dikandungnya, penularan beberapa jenis penyakit dapat menimbulkan infeksi pada palasenta dan janin. Bisa mengakibatkan pedet lahir dalam kondisi lemah atau bisa juga mengakibatkan kematian. Oleh karena itu perlu diantisipasi dengan memantau profil hematologi sebagai indikator tingkat kesehatan sapi lebih awal sebelum sapi memperlihatkan tanda klinis sakit. Pemeriksaan hematologi yang sering digunakan untuk mengukur derajat kesehatan hewan adalah jumlah sel darah merah (eritrosit), kadar hemoglobin $(\mathrm{Hb})$ dan persentase hematokrit (PCV) (Schalm, 2010). Akan tetapi untuk menginterpretasi hasil pemeriksaan laboratorium dibutuhkan pengetahuan fisiologis darah dan parameter acuan darah normal sapi bali pada perioda kebuntingan. Total sel darah merah dapat mengindikasikan terjadinya anemia atau tidak, hematokrit menandakan sapi mengalami dehidrasi atau tidak, total 
leukosit dan diferensialnya dapat memberikan tanda terjadi atau tidaknya infeksi (Amulic et al.,2012). Semua indikator ini akan dapat memberikan gambaran sehat atau tidaknya sapi bunting. Permasalahan yang ada hingga saat ini belum ada laporan mengenai gambaran darah sapi bali pada periode kebuntingan. Dengan alasan tersebut perlu dilakukan penelitian.

\section{METODE PENELITIAN}

\section{Sampel}

Penelitian ini menggunakan 28 ekor sapi bali yang dipelihara di sentra pembibitan sapi bali di desa Sobangan, Kabupaten Badung. Darah diambil melalui vena jugularis dan ditampung ke dalam tabung yang berisi antikoagulan (EDTA).

\section{Pemeriksaan hematologi}

Pemeriksaan menggunakan alat Animal Blood Counter iCell-800 Vet, sampel darah sebanyak 0,2 uL dimasukkan ke mesin yang telah diseting untuk pemeriksaan darah sapi, kemudian hasil hemogram akan tercetak secara otomatis dalam bentuk print out.

\section{Analisis data}

Data yang diperoleh dianalisis dengan Analisis Ragam dengan prosedur analisis menggunakan program SPSS (Nasoetion dan Barizi, 1980).

\section{HASIL DAN PEMBAHASAN}

Hasil penelitian berupa kadar total eritrosit, total leukosit, $\mathrm{PCV}, \mathrm{Hb}$, differensial leukosit (limfosit, neutrofil, basofil, eosinofil dan monosit), MCHC, MCV dan MCH Sapi bali pada perioda kebuntingan di Sentra Pembibitan Sobangan Badung, terhadap 21 ekor sapi bunting dan 7 ekor sapi tidak bunting. Perioda kebuntingan yang diamati adalah triwulan pertama (umur kebuntingan 0 sampai dengan 3 bulan), triwulan ke dua (umur kebuntingan 4 sampai dengan 6 bulan) dan triwulan ke tiga (umur kebuntingan 7 sampai dengan 9 bulan). Data dianalisis dan disajikan pada Table 1.

Tabel 1. Kadar Leukosit, Neutrofil, Limfosit, Monosit, Eosinofil, Basofil, Eritrosit, Hb, PCV, MCV, dan MCHC Sapi bali dalam Perioda Kebuntingan

\begin{tabular}{lcccc}
\hline \multirow{2}{*}{ Parameter } & \multicolumn{3}{c}{$\begin{array}{c}\text { Perioda Kebuntingan } \\
\text { Kadar Rata-rata } \pm \text { SD }\end{array}$} & $\begin{array}{c}\text { Tidak Bunting } \\
\text { Kadar Rata-rata } \\
\pm \text { I }\end{array}$ \\
\cline { 2 - 4 } $\begin{array}{l}\text { Leukosit } \\
\left(10^{3} / \mathrm{ml}\right)\end{array}$ & $9,787 \pm 1,477$ & $9853 \pm 1,477$ & $8,706 \pm 1.478$ & $8,659 \pm 1,478$ \\
$\begin{array}{l}\text { Neutrofit } \\
\left(10^{3} / \mathrm{ml}\right)\end{array}$ & $0,641 \pm 0,465$ & $0,516 \pm 0,466$ & $0,911 \pm 0.465$ & $0,146 \pm 0,465$ \\
Limfosit & $7,704 \pm 1,304$ & $7,879 \pm 1,303$ & $6,857 \pm 1.303$ & $7,684 \pm 1,304$ \\
$\left(10^{3} / \mathrm{ml}\right)$ & & & & \\
Monosit & $0,720 \pm 0,133$ & $0,609 \pm 0,133$ & $0,637 \pm 0.133$ & $0,526 \pm 0,133$ \\
$\left(10^{3} / \mathrm{ml}\right)$ & & & & \\
Eosimofil & $0,049 \pm 0,082$ & $0,064 \pm 0,083$ & $0,49 \pm 0.082$ & $0,064 \pm 0,083$ \\
$\left(10^{3} / \mathrm{ml}\right)$ & & & & \\
Basofil & $0,639 \pm 0,350$ & $0,760 \pm 0,350$ & $0,237 \pm 0.350$ & $0,223 \pm 0,350$ \\
$\left(10^{3} / \mathrm{ml}\right)$ & & & & \\
RBC $\left(10^{6} / \mathrm{ml}\right)$ & $5,173 \pm 0,538$ & $5,456 \pm 0,537$ & $5,116 \pm 0.537$ & $4,533 \pm 0,538$ \\
$\mathrm{HB}(\mathrm{g} / \mathrm{dl})$ & $10,557 \pm 1,069$ & $10,843 \pm 1,069$ & $10,971 \pm 1.070$ & $9,586 \pm 1,069$ \\
PCV $(\%)$ & $28,943 \pm 2,760$ & $29,186 \pm 2,760$ & $29,871 \pm 2.761$ & $26,400 \pm 2,760$ \\
MCV (fL) & $56,514 \pm 5,099$ & $53,471 \pm 5,099$ & $58,986 \pm 5.098$ & $58,571 \pm 5,099$ \\
MCH (pg) & $20,529 \pm 1,596$ & $19,843 \pm 1,596$ & $21,629 \pm 1.596$ & $21,257 \pm 1,596$ \\
MCHC (g/dl) & $36,471 \pm 0,827$ & $37,114 \pm 0,827$ & $36,729 \pm 0.826$ & $36,314 \pm 0,827$ \\
\hline
\end{tabular}


Tabel 2. Hasil Analisis Ragam Kadar Leukosit, Neutrofil, Limfosit, Monosit, Eosinofil, Basofil, Eritrosit, Hb, PCV, MCV, dan MCHC Sapi bali dalam Perioda Kebuntingan

\begin{tabular}{llllll}
\hline $\begin{array}{l}\text { Dependent } \\
\text { Variable }\end{array}$ & $\begin{array}{l}\text { Type III Sum ofdf } \\
\text { Squares }\end{array}$ & Mean Square & F & Sig. \\
\hline Leukosit $\left(10^{3} / \mathrm{ml}\right)$ & 9,086 & 3 & 3,029 & 0,844 & 0,483 \\
Neutrofit $\left(10^{3} / \mathrm{ml}\right)$ & 2,125 & 3 & 0,708 & 1,987 & 0,143 \\
Limfosit $\left(10^{3} / \mathrm{ml}\right)$ & 4,399 & 3 & 1,466 & 0,525 & 0,669 \\
Monosit $\left(10^{3} / \mathrm{ml}\right)$ & 0,135 & 3 & 0,045 & 1,542 & 0,229 \\
Eosimofil $\left(10^{3} / \mathrm{ml}\right)$ & 0,002 & 3 & 0,001 & 0,051 & 0,984 \\
Basofil $\left(10^{3} / \mathrm{ml}\right)$ & 1,594 & 3 & 0,531 & 2,638 & 0,073 \\
Eritrosit $\left(10^{6} / \mathrm{ml}\right)$ & 3,150 & 3 & 1,050 & 2,209 & 0,113 \\
HB $(\mathrm{g} / \mathrm{dl})$ & 8,250 & 3 & 2,750 & 1,463 & 0,249 \\
PCV $(\%)$ & 48,420 & 3 & 16,140 & 1,289 & 0,301 \\
MCV $(\mathrm{fL})$ & 133,329 & 3 & 44,443 & 1,040 & 0,393 \\
MCH (pg) & 13,191 & 3 & 4,397 & 1,050 & 0,388 \\
MCHC $(\mathrm{g} / \mathrm{dl})$ & 2,563 & 3 & 0,854 & 0,761 & 0,527 \\
\hline
\end{tabular}

Keterangan: Semua variabel tidak berbeda nyata $(\mathrm{P}>0.05)$

Dari hasil pemeriksaan kadar leukosit, neutrofil, limfosit, monosit, eosinofil, basofil, eritrosit, $\mathrm{Hb}$. PCV, MCV, MCH, dan MCHC Sapi bali dalam periode kebuntingan (pada Tabel 2) tidak nampak adanya perbedaan dengan sapi yang tidak bunting $(\mathrm{P}>0,05)$. Begitu pula setelah dianalisis lebih lanjut dengan analisis ragam pada setiap perioda kebuntingan kadar dari unsur - unsur yang diteliti tidak menunjukkan perbedaan yang nyata dengan sapi yang tidak bunting.

Hasil penelitian ini terhadap kadar total sel darah putih dan diferensial sel darah putih (neutrofil, limfosit, monosit, eosinofil, dan basofil) sapi bunting mulai dari awal kebuntingan cenderung ada peningkatan dan memiliki rata-rata lebih tinggi dari sapi bali tidak bunting, begitu pula lebih tinggi dari rata-rata sapi umum $\left(8,0 \times 10^{3} / \mathrm{ml}\right)$ atau standar normal sapi (Scalm et al., 2010), akan tetapi masih dalam kisaran normal. Leukosit memiliki peranan yang penting dalam mempertahankan kondisi tubuh dari benda asing (Lawhead dan Baker, 2004). Jumlah leukosit pada umumnya meningkat jika tubuh terinfeksi oleh mikroorganisme dari luar tubuh. Total dan tipe sel darah putih dapat digunakan untuk mendiagnosis status infeksi pada ternak. Sistem imun pada mamalia betina cenderung lebih aktif pada periode kebuntingan dan awal postpartum.
Hal ini berkaitan dengan pembentukan antibodi anak dan juga infeksi pada organ reproduksi. Pisek et al. (2008) menyatakan bahwa peningkatan dan penurunan jumlah leukosit selama masa kebuntingan dan postpartum dipengaruhi pula oleh jumlah limfosit dan neutrofil. Begitu pula peningkatan jumlah leukosit (leukositosis) sering disebabkan oleh infeksi Umum, infeksi lokal, intoksikasi, obat-obatan, dan pertumbuhan neoplasma yang ganas, sedangkan penurunan jumlah leukosit (leukopenia) biasanya disebabkan oleh perubahan di dalam sumsum tulang, infeksi virus, bakteri, kelemahan, pengaruh fisik (radiasi sinar $\mathrm{x}$ atau radio aktif) dan alergi (Coles, 1980)

Eritosit atau sel darah merah (RBC) di dalam aliran darah mamalia merupakan selsel yang tidak berinti dan tidak bergerak (Schalm et al., 2010). Hasil penelitian ini (Table 1), dapat kita lihat sel darah merah (RBC), Hb, PCV, MCH, MCV, dan MCHC terjadi peningkatan seiring dengan fase kebuntingan walaupun peningkatan ini tidak berbeda nyata dengan sapi bali yang tidak bunting dan masih dalam batas nilai normal (Schalm, 2010; Siswanto, 2011, Sri dan Beni, 1983, Utama et al., 2001). Eritrosit pada awal perkembangan embryo, diproduksi di kantung kuning telur. kemudian dibuat di hati. limpa dan kelenjar-kelenjar getah bening. Setelah 
hewan lahir pembentukan eritrosit berlangsung di sumsum tulang. Faktor yang mempengaruhi kualitas eritrosit bukan saja jumlah sel- selnya tetapi juga kadar $\mathrm{Hb}, \mathrm{PCV}$ dan kadar konstituen darah lainnya. Faktor lain yang dapat mempengaruhi kualitas eritrosit adalah, umur, sex, gizi, kehamilan, laktasi, iklim, fase estrus dan ketinggian lokasi. Bila pada ternak ruminansia terjadi defisiensi vitamin dapat menyebabkan gangguan pertumbuhan dan perkembangan eritosit misalnya penyakit anemia terjadi apabila jumlah sel-sel darah merah yang fungsional atau jumlah hemoglobin berkurang jauh di bawah keadaan normal, sebaliknya peningkatan jumlah sel darah merah disebut polisitemia. Biasanya peningkatan kadar sel darah merah tidak memberikan pengaruh dan bahkan dikatakan lebih baik dan lebih sehat. Seiring dengan peningkatan $\mathrm{RBC}$, hemoglobinpun akan meningkat dan sebanding juga dengan peningkatan PCV. Sel darah merah akan meningkat apabila hewan dalam keadaan takut atau hewan dalam keadaan gembira. Hal ini di sebabkan karena dilepaskannya katekolamin (epineprin/norepineprin). Akibatnya tekanan darah meningkat dan di sertai kontraksi dari limpa sehingga ertrosit akan di pindahkan untuk ikut aliran darah. Sedangkan peningkatan PCV bisa diakibatkan hewan kekurangan minum, akibat epineprin dan polisitremia.

Nilai MCV, MCH, dan MCHC dapat digunakan untuk mendiagnosis keadaan anemia pada ternak dan dapat digunakan untuk mengukur kapasitas sumsum tulang untuk meproduksi eritrosit (Njidda et al., 2014). Jilani dan Iqbal (2011) menyatakan defisiensi vitamin-B12, vitamin-A, vitamin-C, vitamin-E, asam folat dan riboflavin berasosiasi dengan kejadian anemia yang disebabkan oleh faktor nutrisi. Nilai MCV dan MCH hasil penelitian ini ternyata tidak berbeda dengan sapi yang tidak bunting. Namun menurut Polizopoulou (2010) jika nilai MCV dan MCH meningkat (macrocytic) akan mengindikasikan respons anemia regenerative yang disebabkan adanya proses hemolisis eritrosit. Nilai MCV yang tinggi juga mungkin disebabkan karena adanya pelepasan sel eritrosit yang belum matang ke dalam sistem sirkulasi darah. Eritrosit yang besar (macrocytic) biasanya memiliki nilai $\mathrm{MCH}$ yang tinggi dan sebaliknya eritrosit yang kecil memiliki nilai $\mathrm{MCH}$ yang rendah (Bashar et al., 2010). Kadar MCHC mengindikasikan konsentrasi haemoglobin per unit volume eritrosit. $\mathrm{MCH}$ tinggi, kadar haemoglobin darah berada pada kisaran normal, sehingga MCHC yang merupakan kadar haemoglobin relatif terhadap ukuran sel setiap sel darah, dapat dikatakan berada pada kisaran normal.

\section{SIMPULAN DAN SARAN}

\section{Simpulan}

Hasil penelitian menunjukkan bahwa kadar total sel darah merah, sel darah putih, $\mathrm{Hb}, \mathrm{PCV}, \mathrm{MCH}, \mathrm{MCHC}, \mathrm{MCV}$, limfosit, neutrofil, monosit, eosinofil, basofil sapi bali pada perioda kebuntingan tidak berbeda dengan sapi yang tidak bunting. Jadi sapi bali di pembibitan Sobangan ini baik yang bunting dan tidak secara klinis sehat dan secara hematologi dapat dikatakan sehat.

\section{Saran}

Karena begitu banyak faktor pemicu maupun penyebab keberhasilan untuk melahirkan anak yang sehat, maka penelitian di segala aspek perlu dilakukan.

\section{UCAPAN TERIMAKASIH}

Penulis mengucapkan terimakasih kepada Dekan Fakultas Kedokteran Hewan Universitas Udayana yang telah memfasilitasi pelaksanaan penelitian ini.

\section{DAFTAR PUSTAKA}

Amulic B, Cazalet C, Hayes GL, Metzler

KD, Zycklinsky A. 2012. Neutrofil 
function: from mechanisms to disease. Ann. Rev. Immunol., 30:459-489.

Arthur GH and Noakes G. 1996. Veterinary reproduction and obstetrics. $5^{\text {th }}$ Ed. Bailliere and Tindall, London.

Bashar YA, Tukur HM, Sekoni AA, Hassam WA. 2010. Nutrient retention and haematological indices of broiler starters fed Lablab seed meal as the source of protein. Nig. J. Basic Appl. Sci., 18(2): 285-291.

Besung INK, Watiniasih NL, Mahardika GNK, Agustina KK, Suwiti NK. 2019. Mineral levels of bali cattle (Bos javanicus) from four different type of land in different rearing areas. Biodiversitas, 20(10): 2931-2936.

Boer M, Arizal PB, Hamdi, 2002. Strategi pemberian pakan tambahan sapi betina bunting dan tidak bunting untuk meningkatkan penampilan reproduksi. Seminar Nasional Peternakan dan Veteriner, Pp. 71-74.

Coles EH. 1980. Veterinan Clinical Patholo Kv. $3^{\text {rd }}$ Ed. WB Saunder Company. Philadelphia. London. Toronto.

Hardjosubroto W, Astuti JM. 1993. Buku Pintar Peternakan. PT Gramedia Widiasarana Press, Jakarta.

Jilani T, Iqbal M. 2011. Does vitamin E have a role in treatment and prevention of anemia? Pak. J. Pharm. Sci., 24(2): 237-242.

Kadarsih S. 2004. Performance sapi bali berdasarkan ketinggian tempat di daerah imigrasi Bengkulu: Perfomance pertumbuhan. J. Ilmu Pertanian Indonesia, 6(6): 50-56.

Laksmi DNDI, Trilaksana IGNB, Darmanta RJ, Darwan M, Bebas IW, Agustina KK. 2019. Correlation between body condition score and hormone level of bali cattle with postpartum anestrus. Indian J. Anim. Res. 53(12): 1599-1603.

Lawhead J, Baker M. 2004. Introduction to Veterinary Science. Clifton Park, USA: Delmar.
Martojo H. 1990. Upaya pemuliaan dan pelestarian sapi bali untuk menunjang pembangunan peternakan secara nasional. Prosiding Seminar Nasional Sapi Bali. Fakultas Peternakan Universitas Udayana, Bali, 20-22 September 1990.

Masudana W. 1990. Perkembangan sapi bali di bali dalam sepuluh tahun terakhir (1980-1989). Seminar Nasional Sapi Bali 20-22 September 1990. Dinas Peternakan Tingkat I Bali.

Nasoetion AH and Barizi. 1980. Metoda Statistika. Jakarta, Penerbit Gramedia.

Ngadiyono N. 1997. Kinerja dan prosfek sapi bali di indonesia, Seminar I AEUP Enviromental Pollution and Natural Product and Bali Cattle in Regional Agriculture, Bali

Njidda AA, Shuai'bu AA, Isidahomen CE. 2014. Haematological and serum biochemical indices of sheep in semiarid environment of Northern Nigeria. Glob. J. Sci. Front. Res., 14(2): 1-9.

Pisek L, Travinicek J, Salat J, Kroupova V, Soch M. 2008. Changes in white blood cells in sheep blood during selenium supplementation. Vet. Med.Czech, 53(5): 255-259.

Polizopoulou ZS. 2010. Haematological test in sheep health management. Small Rum. Res., 92: 88-91.

Schalm OW. 2010. Veterinary Hematology. $6^{\text {th }}$ Ed. Wiley- Blackwell, Singapore.

Siswanto. 2011. Gambaran sel darah merah sapi bali (studi rumah potong). Buletin Vet. Udayana, 3(2): 99-105.

Sri W, Benni M. 1983. Observasi pada hematologi sapi bali. Proc. Petemuan Ilmiah Ruminansia Besar. Pusat Penelitian Dan Pengembangan Peternakan, BPPP Deptan, Bogor. Pp. 177-180.

Utama IH. 2001. Karakteristik anemia sapi bali. J. Vet. 2(1): 13-16. 